\title{
Drought-induced oak decline in the western Mediterranean region: an overview on current evidences, mechanisms and management options
}

\section{to improve forest resilience}

\author{
Tiziana Gentilesca ${ }^{(1)}$, \\ J Julio Camarero ${ }^{(2)}$, \\ Michele Colangelo ${ }^{(1)}$, \\ Angelo Nolè (1), \\ Francesco Ripullone ${ }^{(1)}$
}

\begin{abstract}
Increased forest vulnerability is being reflected as more widespread and severe drought-induced decline episodes. In particular, the Mediterranean area is revealing a high susceptibility to phenomena of loss in tree vitality across species. Within tree species, oaks (Quercus spp.) are experiencing extensive decline in many countries. However, in the wake of the so-called "oak decline phenomenon", the attention on these species has generally been limited. In this paper, we review the current available literature on oakdecline cases reported within the Mediterranean Basin, with particular remark for those occurred in Italy and Spain. More specifically our main aims were to: (i) provide an update on the patterns and mechanisms of decline by focusing on tree-ring and wood-anatomical variables; (ii) provide some hints for improving the resistance and resilience of oak stands experiencing decline. Our review reveals that drought is reported as the main driver triggering oak decline within the Mediterranean Basin, although other causes (i.e., increasing temperature, pathogens attack or excessive stand density) could exacerbate decline. In most reported cases, drought induced a substantial reduction of growth and changes in some wood anatomical properties. Indeed, growth decline prior death is also indicated as an early-warning signal of impending death. In ring-porous oak species, declining trees were often characterized by a very low production of latewood and a decrease in lumen area of the widest earlywood vessels, suggesting a potential reduction of hydraulic conductivity. Moreover, hydraulic dysfunction is reported as the main cause of decline. Finally, regarding management actions that should be considered for improving the resilience of declining stands and preserve the species-specific stand composition, it could be useful to shorten the rotation period of coppice stands or promoting their gradual conversion towards high forests, and favor ing more drought-resistant species should also be considered. In addition, regeneration prior to regeneration cuts should be improved by anticipating seed dispersal or by planting oak seedlings obtained from local germoplasm.
\end{abstract}

Keywords: Growth, Adaptive Forest Management, Quercus, Resilience, Forest Dieback

standing the causes of such decline and predicting its consequences has emerged as one of the greatest challenges for the international scientific community. The 88 cases of forest drought- and heat-induced tree mortality documented by Allen et al.
(1) School of Agricultural, Forest, Food and Environmental Sciences, University of Basilicata, Potenza (Italy); (2) Pyrenean Institute of Ecology (IPE-CSIC), Avda. Montañana 1005, 50192 Zaragoza (Spain)

@ Tiziana Gentilesca (tiziana.gentilesca@unibas.it)

Received: Dec 15, 2016 - Accepted: Jul 12, 2017

Citation: Gentilesca T, Camarero JJ, Colangelo M, Nolè A, Ripullone F (2017). Droughtinduced oak decline in the western Mediterranean region: an overview on current evidences, mechanisms and management options to improve forest resilience. iForest 10: 796-806. - doi: 10.3832/ifor2317-010 [online 2017-09-25]

Communicated by: Tamir Klein
(2010) had almost doubled in 2014, involving more areas and biomes (Hartmann et al. 2015), and testifying an increasing scientific attention appreciable in terms of number of published studies. In fact, searching the terms "forest, drought and mortality" in the ISI Web of Knowledge ${ }^{\circledast}$ database returns an increasing number of papers, which almost tripled in 2016 (213 papers) compared to 2010 (73 papers - Fig. 1).

Most of these studies reported widespread reductions of growth and increased mortality worldwide, which affect several tree species and biomes, including tropical forests (Fisher et al. 2007), temperate mountain conifer and hardwood forests (Linares \& Camarero 2012, Anderegg et al. 2013), drought-prone mountain conifer forests (Adams et al. 2013), Mediterranean conifer forests (Linares et al. 2009) and Mediterranean oak forests (Lloret et al. 2004, Camarero et al. 2015a, 2015b, 2016).

The Mediterranean region has been iden- 
Fig. 1 - Temporal trend of the number of published studies containing the terms "drought, forest, mortality". These studies were published from 2000 to 2016, and were retrieved from the ISI Web of Knowledge ${ }^{\circledast}$ database.

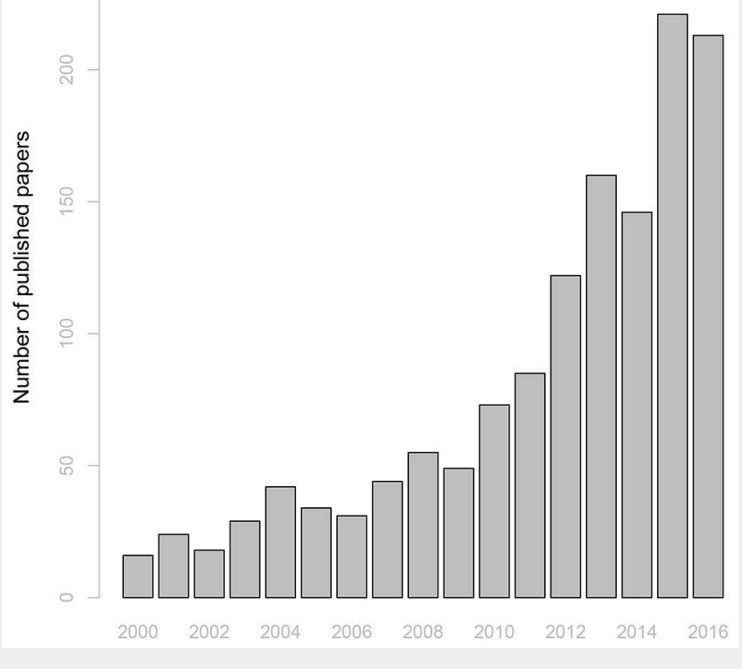

tified as one of the climate-change hotspots with major risks in the near future, including warmer and drier conditions (IPCC 2014). These trends would imply that more forest areas will become particularly vulnerable under drier conditions. These more drought-susceptible areas across the Mediterranean Basin include oak (Quercus spp.) forests that represent one of the most widespread genus across the Northern hemisphere (Nixon 2006), and it is considered of great importance in ecological, cultural and economical terms across the Mediterranean Basin (Barbero et al. 1992). However, despite the relevance of Mediterranean oak forests, the biogeographical patterns and the management implications of decline episodes in this type of forest have not been deeply investigated.

In this paper, we discuss the available knowledge on oak decline in the western Mediterranean area by analyzing concrete evidences from two study cases in Italy and Spain, where oak forests are experiencing decline episodes. Moreover, we propose useful actions of adaptive forest management for improving the resilience and resistance of declining oak stands within the Mediterranean area.

\section{The oak decline phenomenon}

Oak decline was first described in 1739 in Germany, and subsequently in Hungary in 1877 (González Alonso 2008); since then, those phenomena were not as frequently reported as in the late $20^{\text {th }}$ century (Delatour 1983, Tainter et al. 1983). Greater attention on this topic started around the 1990 s after the first international congress held in Poland (Siwecki \& Liese 1991).

Currently, it is widely recognized that oak decline is an ongoing phenomenon in Europe since at least the early 1980 s. Its incidence seems to spread over larger areas in southern Europe, at least in the two countries compared here, namely Spain and Italy (Fig. 2). Furthermore, oak decline seems to be a global phenomenon, as it has been also described in Japan (Nakajima \& Ishida 2014) and northern America (Elliott \& Swank 1994).

In the Mediterranean Basin, the Spanish authorities officially recognized oak decline (the so-called "la seca") since the 1990s, to designate a group of symptoms where many different parasitic agents can be involved, giving rise to a process of quick loss in tree vigor (González Alonso 2008). La seca occurred more frequently at savanna-type dehesas (i.e., a high forest with scattered and pruned adult trees which is commonly exploited as an agro-silvopastoral system), where the affected oak trees (usually Q. ilex and Q. suber), showed a rapid death often connected to a disease caused by the Phytophtora cinnamomi pathogen (Brasier 1992, 1996, González Alonso 2008). However, decline episodes have been also detected in Spanish temperate oak forests (Rozas \& García-González 2012, Rozas \& Sampedro 2013) and mainly in low drought-prone oak forests, often formerly coppiced (Corcuera et al. 2004a, Corcuera et al. 2004b, Lloret et al. 2004, Corcuera et al. 2006).

In Italy, isolated oak decline cases have been observed since the end of the last century. Such decline has been always considered as a sporadic phenomenon of sitespecific importance (i.e., local or regional), due to the fragmentation of local reports, thus it has not been object of adequate attention at the national level so far. Initially identified in northeastern Italy forests, where Q. robur was the most affected species, it has spread thereafter in central and southern Italy, mainly on Q. cerris, Q. frainetto and $Q$. pubescens in both pure and mixed forests (Barzanti et al. 2001, Di Filippo et al. 2010, Sala et al. 2011). Nevertheless, relatively few studies on oak decline have been carried out to date (Barzanti et al. 2001, Vettraino et al. 2002, Linaldeddu et al. 2007, Di Filippo et al. 2010, Sala et al. 2011, De Nicola et al. 2014).

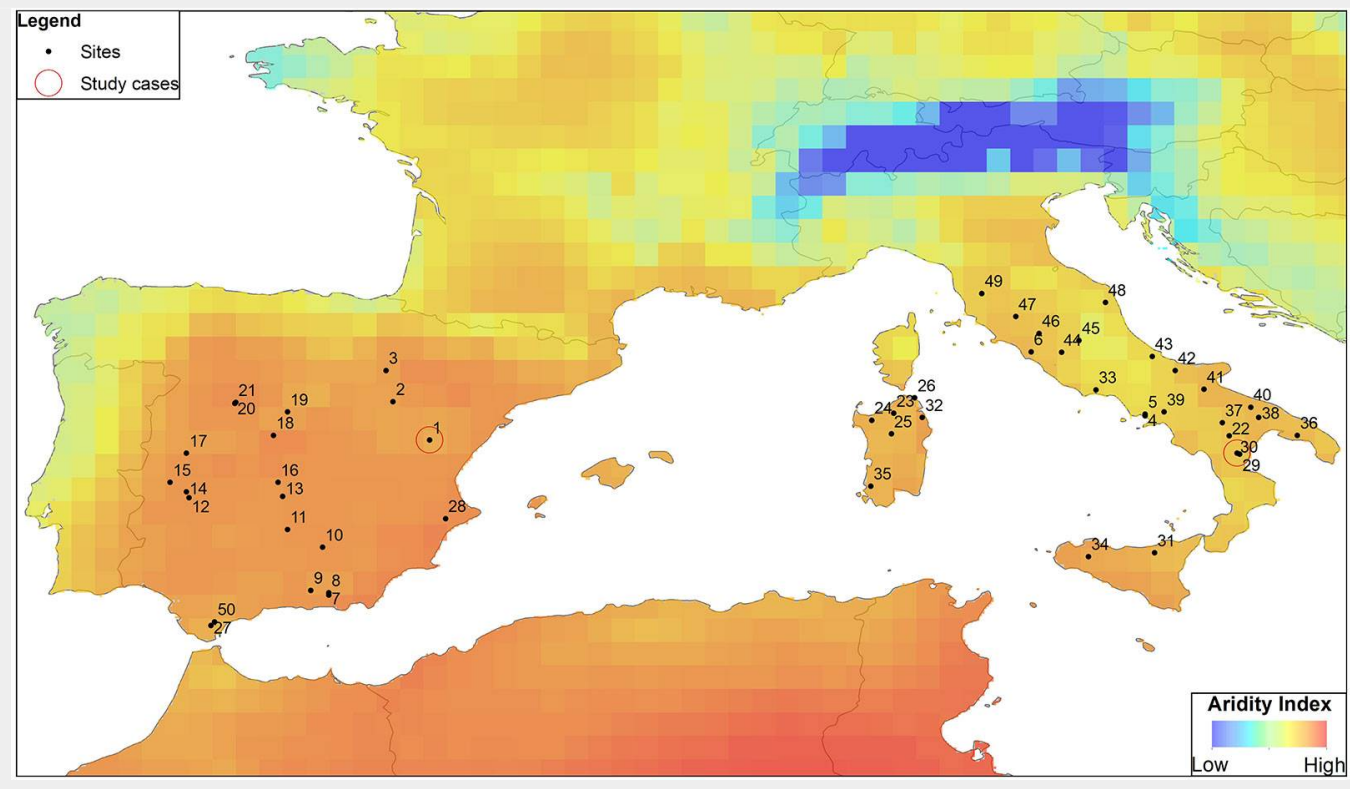

Fig. 2 - Location of sites in the western Mediterranean Basin, with particular focus on Italy and Spain, reporting oak decline, as retrieved from literature studies. Background colors in the map indicate the aridity index, evaluated as the ratio between precipitation and potential evapotranspiration for the 2007-2012 period. Climate data were obtained from the $0.5^{\circ}$-gridded Climatic Research Unit (CRU TS 3.23) climate dataset. Red circles indicate the study cases reported in the text. 

Causes and mechanisms leading to
oak decline

The oak decline is widely recognized as a complex phenomenon due to multiple causes that occur slowly over several years, even if mortality can suddenly follow decline. Manion (1991) conceptualized the tree decline by categorizing predisposing, inciting and contributing factors. For example, predisposing factors might be associated with high competition or the presence of shallow, rocky soils, ridge top and upper slope site locations; inciting factors are interconnected to extreme climatic events as dry spells, and contributing factors are often related to secondary factors (e.g., pathogens), affecting trees already weakened. However, recent findings suggest that long-term or acute drought stress often act as a major driver of oak decline, usually linked to site-specific soil conditions, such as the characteristics of soil parent material that inhibits root development or access to groundwater (Costa et al. 2010), the low organic horizon that in some cases can lead to a nutrient deficiency (Demchik \& Sharpe 2000) or to a low water retention capacity (Allen et al. 2010). Therefore, the conceptual model of Manion (1991) is not always easily transferable to study cases where the same factor (e.g., drought stress) acts at different time scales and can predispose, incite or contribute to oak decline.

In general, hydraulic failure induced by drought is considered the primary mechanism responsible of widespread decline of several forest species around the globe including oaks, which are mainly anisohydric species (Choat et al. 2012). Droughtinduced xylem embolism reduces the capacity of plants to move water from roots to leaves, altering the tree's hydraulic system and leading trees to shoot and canopy dieback, leaf desiccation and branch mortality (Adams et al. 2013). Although the hydraulic failure is recognized as the main mechanism of decline, other mechanisms are often reported, such as the phloem dysfunction and carbon starvation, in addition to biotic stressors as fungi, bacteria and insects (McDowell et al. 2008).

For example, recent studies evidenced how some functional traits as wood density (Greenwood et al. 2017), stand conditions as inter- and intra-specific competition, the level of crown transparency or the size and age of plants, co-act with drought in leading to decline. In fact, in accordance with Martínez-Vilalta et al. (2011), intra- and interspecific competition exacerbates the negative effects of drought predisposing plants to decline. Furthermore, according to recent studies (Camarero et al. 2016, Colangelo et al. 2017a), small plant size and low growth rates in the period before decline significantly predisposed some oak species to drought-induced decline (see also McDowell \& Allen 2015).

Although drought is identified as the first cause of oak decline in most Mediterranean sites across Italy or Spain, in a temperate Q. robur forest located in northwestern Spain the decline was attributed to excessively elevated soil moisture (Rozas \& García-González 2012). Indeed, the excess of soil water may lead to root death, increasing the predisposition of trees to other stressors (Marçais \& Bréda 2006).

\section{Updating evidences of widespread oak decline in the western Mediterranean (Italy and Spain) from literature studies}

We conducted a literature search through the ISI Web of Knowledge ${ }^{\circledast}$ database, and we initially selected published papers addressing the oak decline topic. Wide ranges of studies reporting evidences of oak de-

Tab. 1 - Summary of literature studies reporting decline of Mediterranean oaks. The main traits observed in studies are reported and the symbols (+/-) indicate the observed effects (positive or negative) on considered variables. Mortality (Mor) indicates the presence of drought-killed trees. Replicated symbols emphasize their intensity. (Sym): presence of decline symptoms; (Pat): pathogens were identified; (TRW): ring width; (LW): latewood; (EW): earlywood; (HC): hydraulic conductivity; (Site number): indicate the correspondences between the published papers and the site location in Fig. 2. The main causes of observed decline are reported according to the published papers. (OR): official report available online; (ns): oak decline attributed to non-specific causes; ( $¥)$ : study sites.

\begin{tabular}{|c|c|c|c|c|c|c|c|c|c|c|}
\hline Reference & $\begin{array}{l}\text { Oak } \\
\text { species }\end{array}$ & TRW & LW & EW & $\mathrm{HC}$ & Sym & Mor & Pat & Causes & $\begin{array}{c}\text { Site } \\
\text { number }\end{array}$ \\
\hline Camarero et al. 2016 & $\begin{array}{l}\text { Mixed } \\
\text { (Q. ilex-Q. faginea) }\end{array}$ & -- & - & - & - & ++ & + & - & drought & $1^{(\ddagger)}$ \\
\hline Corcuera et al. 2004a, 2004b & $\begin{array}{l}\text { Mixed } \\
\text { (Q. ilex-Q. faginea) }\end{array}$ & -- & --- & -- & -- & ++ & + & - & drought & 2 \\
\hline Corcuera et al. 2006 & Q. pyrenaica & -- & 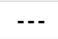 & -- & - & ++ & - & - & overaging & 3 \\
\hline De Nicola et al. 2014 & Q. ilex & - & - & - & - & - & - & - & ns & 4,5 \\
\hline Di Filippo et al. 2010 & Q. cerris & -- & - & - & - & - & - & - & drought & 6 \\
\hline Gea-Izquierdo et al. 2013 & Q. pyrenaica & - & - & - & - & - & - & - & high temperature & $7-14,16,19,20$ \\
\hline Gea-Izquierdo et al. 2013 & Q. ilex & - & - & - & - & - & - & - & high temperature & $15,17,18,21$ \\
\hline Gentilesca et al. 2015 & Q. cerris, pubescens & -- & - & - & - & +++ & - & - & drought & 22 \\
\hline Linaldeddu et al. 2007 & Q. suber & - & - & - & - & ++ & - & ++ & pathogens & 23 \\
\hline Linaldeddu et al. 2009 & Q. suber & - & - & - & - & ++ & - & ++ & pathogens & 24 \\
\hline Linaldeddu et al. 2010 & Q. suber & - & - & - & - & ++ & - & ++ & pathogens & 25 \\
\hline Morillas et al. 2011 & Q. suber & - & - & - & - & ++ & - & - & tree nutritional status & 27 \\
\hline Perez-Sierra et al. 2013 & Q. suber & - & - & - & - & +++ & - & ++ & low temperatures & 28 \\
\hline Colangelo et al. 2017a, 2017b & Q. frainetto & -- & - & - & - & ++ & + & - & drought & $29^{(\ddagger)}, 30^{(\ddagger)}$ \\
\hline Sala et al. 2011 & Q. gussonei & - & - & - & - & +++ & - & - & ns & 31 \\
\hline Scanu et al. 2013 & Q. suber & - & - & - & - & ++ & - & ++ & pathogens & 32,33 \\
\hline Vettraino et al. 2002 & Q. cerris & - & - & - & - & ++ & - & ++ & ns & $34,37,39,42-29$ \\
\hline Vettraino et al. 2002 & Q. ilex & - & - & - & - & ++ & - & ++ & ns & 35,36 \\
\hline Vettraino et al. 2002 & Mixed & - & - & - & - & ++ & - & ++ & ns & $38,40,41$ \\
\hline Avila et al. 2016 & Q. suber & - & - & - & - & ++ & +++ & ++ & pathogens & 50 \\
\hline Brasier 1996 & Mixed & - & - & - & - & - & - & - & temperature & - \\
\hline Banqué Casanovas et al. $2013^{(\mathrm{OR})}$ & Mixed & -- & - & - & - & ++ & - & + & pathogens & - \\
\hline Costa et al. 2010 & Q. suber & - & - & - & - & ++ & + & - & site-specific & - \\
\hline De Sampaio et al. 2013 & Q. suber & - & - & - & - & ++ & + & ++ & interaction of factors & - \\
\hline Fernandez-Escobar et al. 1999 & Mixed & - & - & - & - & - & ++ & - & ns & - \\
\hline
\end{tabular}



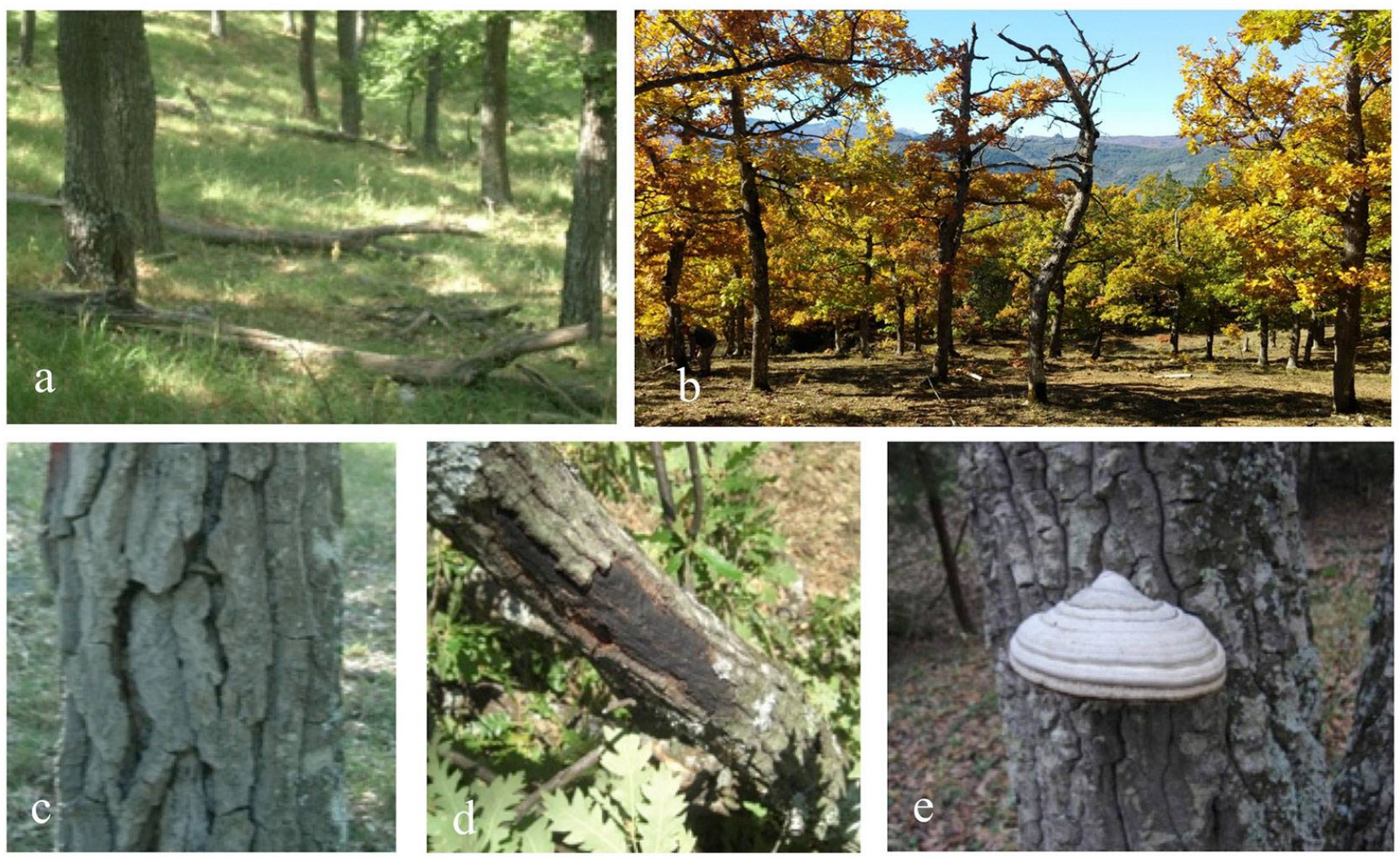

Fig. 3 - Evidences of decline observed in oak forest stands from Southern Italy: (a) presence of dead trees; (b) diffuse brown crowns and increased crown transparency (defoliation); (c) detachment of bark; and trunk damages caused by pathogen agents such as fungi (d: Fomes fomentarius; e: Hypoxilon mediterraneum).

cline from Europe were collected; however, we selected only studies conducted in the western Mediterranean Basin, with particular focus on Italy and Spain (Tab. 1).

Overall, 50 sites showing decline symptoms (crown dieback, leaf shedding, abundant dead branches or shoots, formation of epicormic shoots, increased tree mortality) were retrieved from literature studies; the stand-specific information (i.e., composition of species and management) were carefully collected from selected study sites.

The composition of sites can be summa rized as follows: mixed stands (6 sites), $Q$. pyrenaica (12 sites), Q. ilex (9 sites), Q. cerris (12 sites), Q. suber (7 sites), Q. frainetto (2 sites), Q. gussonei (1 site), and Q. faginea (1 site). According to the distribution ranges of considered species, the elevation of sites spans from o up to 1600 meters above sea level, corresponding to Q. suber, Q. cerris, Q. ilex, and mixed stands situated at the lowest (100-500 $\mathrm{m}$ a.s.l.), and $Q$. pyrenaica, Q. frainetto, Q. gussonei, $Q$. faginea stands located at the highest (800$1200 \mathrm{~m}$ ) elevation, respectively.

Therefore, 25 papers carried out on oak decline stands with trees growing in drought-prone areas from Mediterranean region were considered, including one national published report available online (Tab. 1).

Most of the considered studies did not directly discuss the decline of oak stands, as they often focused on pathogen attacks and soil-water dynamics. During the last decades, several defoliating insects species have been reported among the main mortality agents of oak forests, particularly in Northern America (see Haavik et al. 2015 for a review). The pathogens associated with the oak decline in Mediterranean areas are generally recognizable as secondary biotic factors (i.e., due to opportunistic organisms that develop as a consequence of the loss in tree vigor), such as root fungi of the Armillaria and Phytophthora genera (De Sampaio et al. 2013, Vettraino et al. 2002, Perez-Sierra et al. 2013), and stem cankers caused by Hypoxylon spp. Within these studies a large variability of symptoms is reported (i.e., foliage rarefaction and wilting, drying of branches, crown dieback, delay of spring bud burst, production of epicormic shoots, longitudinal cracks of the bark which is often detached, reduction of biomass, necrotic lesions and necrosis of absorbing roots - Fig. 3 and Fig. 4). Moreover, a reduction of primary and secondary growth and leaf area index often translates into increased risk of tree mortality.

In the following section we underline the main characteristics of declining oak trees as depicted from tree-ring and woodanatomical features based on published studies. Moreover, we compare site-specific evidences from two recent studies carried out in declining oak stands from the
Mediterranean region to assess differences between declining and non-declining trees. Two sites subjected to Mediterranean conditions and characterized by frequent and severe droughts were chosen, the first located in eastern Spain (Camarero et al. 2016) and the second in southern Italy (Colangelo et al. 2017a, 2017b). These countries provide ideal settings to compare temperature effects on drought severity, since Italy is subjected to more temperate conditions, whereas most of the Peninsular Spain is subjected to more continental conditions. Moreover, the forecasted warmer conditions would exacerbate drought stress in the continental Iberian Peninsula compared to the more temperate Italian Peninsula, with severe consequences for forest ecosystems. Site-specific study cases were chosen in order to compare two broadleaf deciduous species (Q. faginea vs. Q. frainetto) forming mixed and pure forest populations managed as coppice ( $Q$. faginea) and high forest (Q. frainetto) stands, respectively.

\section{Drawing a declining oak from tree- rings}

Studies on quantitative wood anatomy and dendrochronology have demonstrated their potential to supply useful information on the causes of tree decline, although this approach is basically observational and retrospective. Detecting growth responses to climate constitutes a powerful tool for 


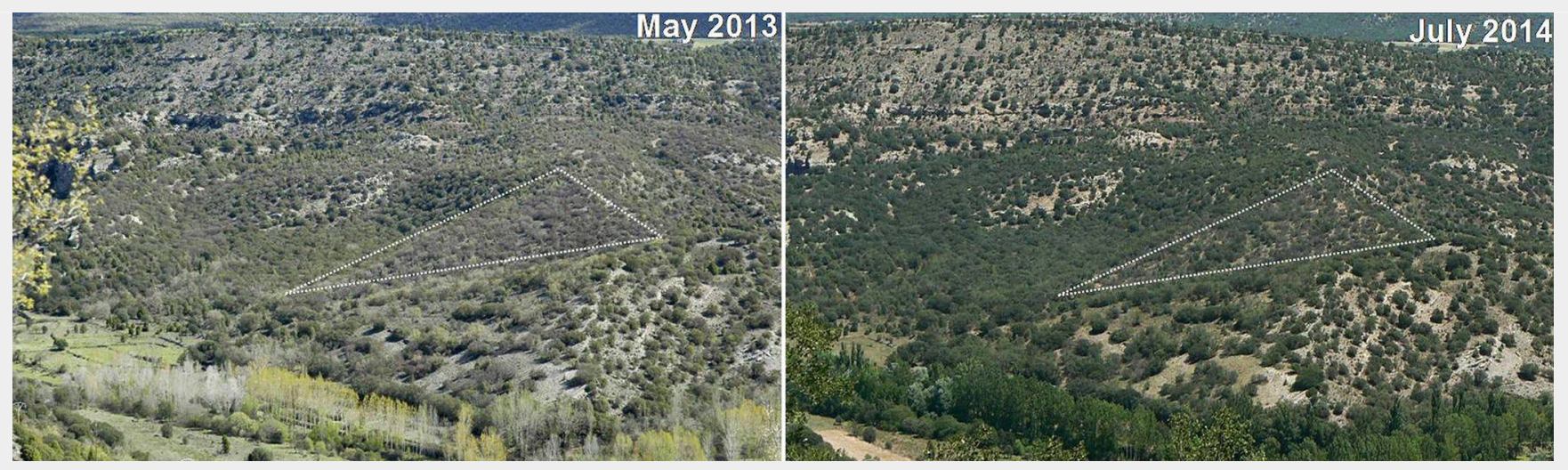

Fig. 4 - Two panoramic views of a Quercus ilex stand affected by the severe 2012 drought and showing canopy dieback and leaf shedding. The site is located in the Teruel province, eastern Spain (Formiche Bajo - 40 $18^{\prime} 02^{\prime \prime} \mathrm{N}, 0^{\circ} 52^{\prime} 14^{\prime \prime} \mathrm{W}, 1120-1150 \mathrm{~m}$ a.s.l.). The triangles identified the most affected area characterized by abundant leaf death and shedding. See more details in Camarero et al. (2016).

understanding forest dynamics under climate-change scenarios especially in cases of forest decline (Linares \& Camarero 2012). Moreover, the long-term reconstruction of wood anatomical features, strictly linked to the evolution of xylem anatomy plasticity through time, allows better investigating tree hydraulic adjustments in response to changing environmental conditions such as drought stress (Corcuera et al. 2006).

By comparing wood variables of declining $v s$. non declining trees, the following differences have been often detected: (i) a reduction of ring width; (ii) reduced diameter of earlywood vessels; (iii) a sharp decrease, or even an absence, of latewood production in ring-porous species; and (iv) abundant lumen vessels filled with tyloses, indicating a potential decrease of xylem hydraulic conductivity.

Most tree species showed a particularly low rate of growth in the years immediately preceding tree death, a feature recently recognized as related to droughtinduced mortality (Berdanier \& Clark 2016). Levanic et al. (2011) stated that periods of low growth rates preceding mortality are consistent with the carbon starvation mechanism of decline, but this does not exclude reduced water transport capacity in the final years before death, due to a low xylem production. Moreover, the reduced growth rate has been observed not only within the period of dieback symptoms occurrence, but also during the whole life of declining trees (Tulik 2014). However, in other studies on oak decline higher growth rates have been described in trees prone to drought-induced damage, particularly in temperate areas where water shortage rarely occurs (Levanic et al. 2011).

In our recent studies carried out on declining oak stands situated in southern Italy ( $40^{\circ} 00^{\prime} 10^{\prime \prime} \mathrm{N}, 16^{\circ} 23^{\prime} 30^{\prime \prime} \mathrm{E}$; $770 \mathrm{~m}$ a.s.l.) and eastern Spain (40 $10^{\prime} 02^{\prime \prime} \mathrm{N}, 0^{\circ} 52^{\prime} 14^{\prime \prime}$ $\mathrm{W} ; 1120-1150 \mathrm{~m}$ a.s.I.) a general and significant decreasing trend in ring width following several drought episodes was found overall after 2000 s in declining trees. This reduction is reflected in an accentuated divergence in terms of basal area increment between declining and non-declining trees (Fig. 5). This irreversible growth decline evidences a long-term predisposition of trees to death (i.e., 10 to 20 years before). The usefulness of such sharp or gradual drops in growth after drought as earlywarning signal of tree death has been proven based on diverse statistical tools (Colangelo et al. 2017b).

Often the growth reduction of declining trees translates in fewer and smaller earlywood vessels, thus leading to a reduced hydraulic conductivity (Fonti et al. 2010). However, drought- and frost-induced xylem cavitation can make earlywood vessels lose their functionality in sites under Mediterranean continental conditions (Cor- cuera et al. 2006) and increase forest susceptibility to further water deficit with subsequent reduced production of latewood. Thus, a drop in latewood production with consequent changes in its wood anatomical features is often observed in declining trees.

\section{Wood anatomy}

Wood anatomical traits are mainly linked to hydraulic conductivity affecting xylem embolism, growth and carbon use (Hoffmann et al. 2011). These traits constitute valuable indicators for determining the vulnerability of trees to water shortage.

Recently, Colangelo et al. (2017b) underlined the presence of very few differences in wood anatomy features by analyzing oak trees belonging to different vigor classes,

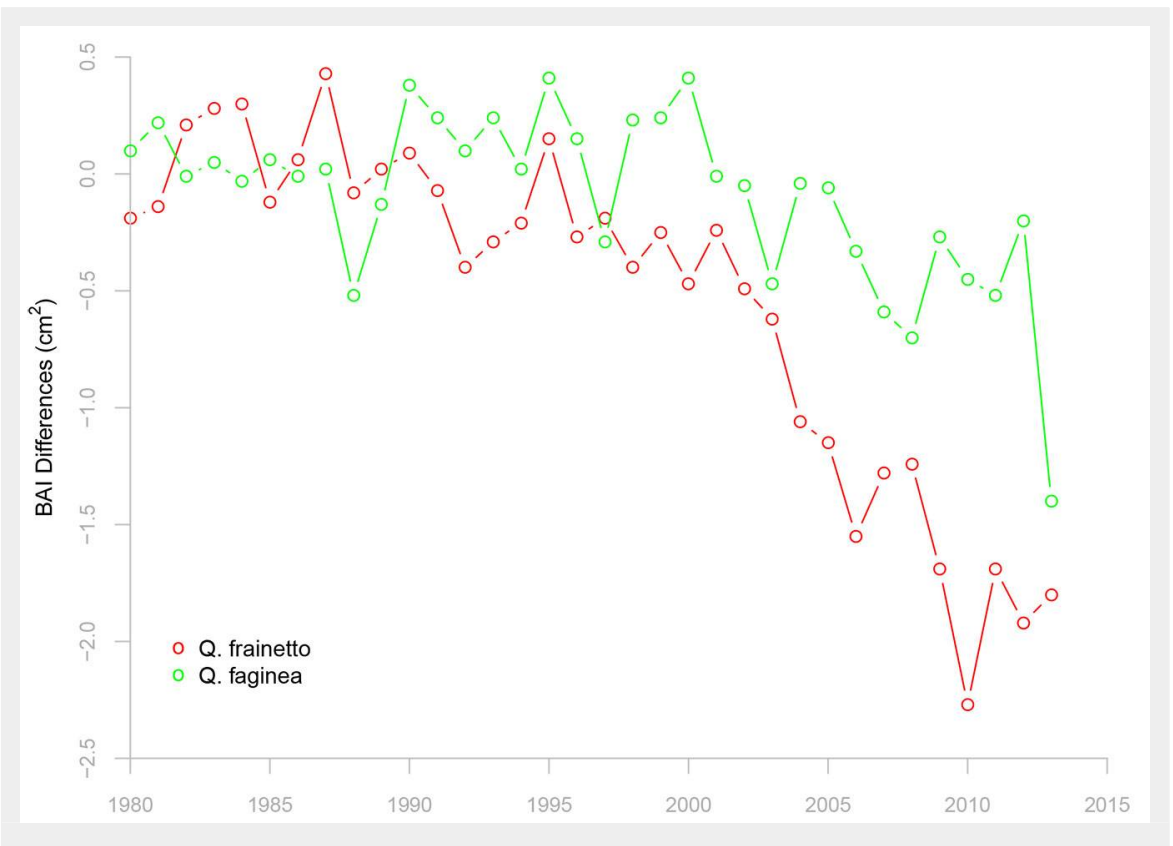

Fig. 5 - Differences in basal area increment (BAI) between declining and non-declining oak trees from two Mediterranean study sites located in eastern Spain (Q. faginea, Formiche Bajo, 40 $10^{\prime} 02^{\prime \prime} \mathrm{N}, 0^{\circ} 52^{\prime} 14^{\prime \prime} \mathrm{W} ; 1120-1150 \mathrm{~m}$ a.s.l.) and southern Italy (Q. frainetto, San Paolo, $40^{\circ} 00^{\prime} 10^{\prime \prime} \mathrm{N}, 16^{\circ} 23^{\prime} 30^{\prime \prime} \mathrm{E} ; 770 \mathrm{~m}$ a.s.l.). The divergence in growth between the two vigor classes abruptly increased after the 2000 s droughts. 
thus suggesting a low plasticity of xylem traits, in response to drought. In that study a higher latewood vessel density was observed in declining trees as compared to non-declining trees (Fig. 6). This divergence was interpreted as a compensation mechanism to provide hydraulic conductivity if earlywood vessels experience embolism.

Rainfall exclusions performed on Q. suber trees under semi-arid conditions underlined a high resilience of this species to inter-annual precipitation variability, with a remarkable recovery capacity after severe drought events (Besson et al. 2014). Moreover, recent observations from NE Spain (Banqué Casanovas et al. 2013) indicated that Q. ilex and Q.suber were vulnerable to drought-induced damage, but they were also able to recover rapidly. In a Q. ilex forest located in NE Spain, the 150 monitored trees showed a mean defoliation of $44 \%$ and $22 \%$ of trees with defoliation $>75 \%$, after the severe 2012 drought, although only 2 (i.e., 1.3\%) of highly defoliated trees died (Camarero et al. 2015a).

Noteworthy, wood anatomy may differ among oak species showing good resilience ability, as demonstrated for species with high wood density (see Gleason et al. 2016 for a review on xylem anatomical features in a global comparison of woody species). However, there is a research gap concerning the variability of wood features within oak species considering individuals of different vigor or showing different vulnerability to drought-induced mortality.
For instance, Greenwood et al. (2017) concluded that tree mortality increased with drought severity, but functional traits as wood density explained less than $10 \%$ of the variation in drought responses, although tree species with denser wood showed lower mortality responses. Remarkably, only $17 \%$ of their 58 study cases considered oak species. O'Brien et al. (2017) also considered wood density as a potential functional proxy of susceptibility to drought-induced mortality, but they failed to find direct relationships between tree growth, functional traits and droughtinduced decline and mortality.

Recent studies have introduced a new interpretation of hydraulic functioning in trees by relating phloem and xylem function (Mencuccini et al. 2015). In this sense, the hydraulic capacitance of trees assumes a key role in xylem vulnerability, more than the water availability itself. This is an open area of research since we lack information on how much water trees are able to store in their sapwood and how it is transported across organs.

\section{Climate-growth relationships}

In general, most studies carried out on declining oak forests showed stand-specific growth responses to climate variables (Corcuera et al. 2004a, 2004b). Furthermore, the few investigations comparing climate-growth relationship among trees of different decline degree, reported slight differences between non-declining and declining trees (Di Filippo et al. 2010, Cama-

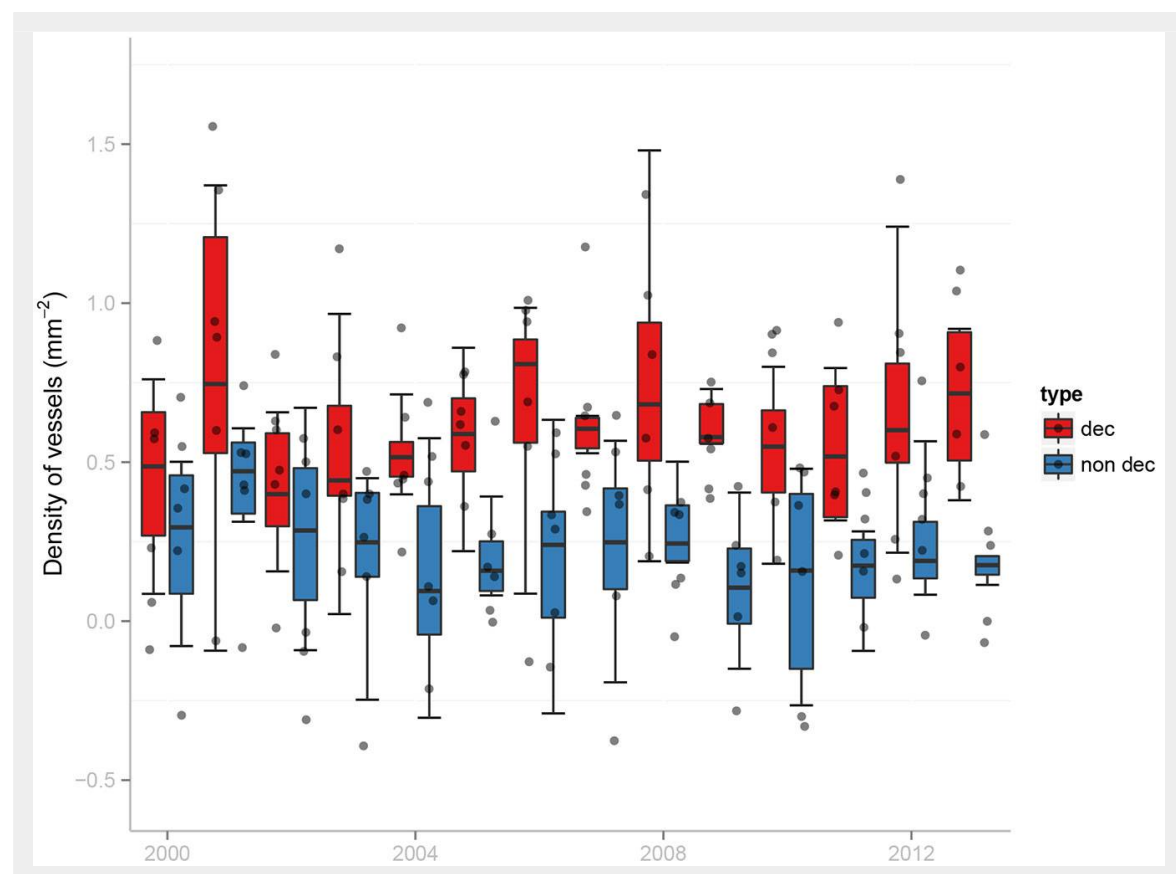

Fig. 6 - Recent trends in latewood vessel density of declining (dec) and non-declining (non dec) Q. frainetto trees in a forest from southern Italy (modified from Colangelo et al. 2017a). The graph shows an increase in latewood vessel density in declining trees. Note that vessel density data are log-transformed. Each box represents the $75^{\text {th }}$ to $25^{\text {th }}$ percentiles, the horizontal line shows the median, the upper and lower marks identify the ranges of variation, and the points located outside the lower-upper mark range are outliers.

rero et al. 2016, Colangelo et al. 2017b).

In the circum-Mediterranean region, oak radial growth is improved by wet and cool conditions during spring and summer (Tessier et al. 1994). In particular, ring-porous and often deciduous oaks typically have high water requirements during the spring (Lebourgeois et al. 2004, Akkemik et al. 2006, Di Filippo et al. 2010), due to their earlier phenology as compared to diffuseporous oaks. Indeed, latter oaks are often evergreen species whose growth depends more on summer water availability (Corcuera et al. 2004a, 2004b, MontserratMartí et al. 2009). Within diffuse-porous oak species, $Q$. ilex and $Q$. suber show a particular sensitivity to spring precipitation (Corcuera et al. 2004a, Gutiérrez et al. 2011, Besson et al. 2014).

In our study cases in southern Italy we found that declining Q. frainetto trees (Fig. 7) responded more negatively to warmer spring conditions (higher mean maximum temperatures) than non-declining trees, whereas correlations with precipitation or with water balance did not differ between the two vigor classes. Interestingly, similar findings were obtained by Camarero et al. (2016) in another Mediterranean ring-porous deciduous oak (Q. faginea). This suggests that heat stress could be a major trigger of dieback in similar Mediterranean oak species. However, this results does not explain why these deciduous species show less drought-induced damage than coexisting diffuse-porous evergreen oak species such as the widespread Q. ilex, which usually reaches a lower height (Camarero et al. 2016). It could be speculated that taller oaks as $Q$. frainetto are more able to retrieve soil water under dry conditions than smaller and drought-vulnerable oak species as Q. ilex. At the same time too warm spring conditions seem to constrain more the radial growth of deciduous oak species as compared with evergreen oaks, since usually the former have an earlier onset of shoot and leaf development than the latter which are able to grow in summer (Montserrat-Martí et al. 2009). Nevertheless, it still remains unknown why evergreen species as Q. ilex, which are widely distributed across the western Mediterranean Basin, are vulnerable to drought-induced damage and why sub-Mediterranean deciduous species ( $Q$. frainetto, $Q$. faginea) which are often found in less dry sites are so sensitive to excessively warm spring conditions. To answer both questions more attention should be paid to extreme climate events as summer dry spells and spring heat waves.

Generally, the investigation of oak decline associated with extreme climatic events as dry spells, showed how either exceptionally wide or narrow rings can be formed prior to tree death, albeit sudden growth reductions are often associated with decline (Wyckoff \& Bowers 2010). A recent study (Berdanier \& Clark 2016) carried out in America on a very large tree sample 
(more than 28,000 observations at the tree level) stated that died trees following drought events had not shown evidence of recovery within the last 10 years. Moreover, surviving trees showed a higher annual growth rate before and following the extreme events, compared to declining and dying trees.

\section{Improving the resilience of declining oak stands through adaptive forest management}

In the last years, the scientific community has shifted from focusing on causes of forest decline to the implementation of management actions aimed at recovering forest ecosystems severely affected by drought. The identification and development of suitable adaptive forest management strategies is essential to improve the resilience of declining stands, particularly if climate becomes warmer and drier. Indeed, these strategies should improve the capacity of stands to resist disturbances by quickly recovering (Elmquist et al. 2003). Thus, the regeneration establishment and ecological succession constitute the main outcome to achieve (Hannah et al. 2002).

Currently, leaf loss or defoliation has been re-evaluated as a proxy to assess the health status of forests. Indeed, the percentage of crown defoliation was found strongly related to mortality rates in drought-prone areas (Carnicer et al. 2011, Cater 2015). Therefore, it can be hypothesized that an increasing probability of decline in oaks is associated with multiple early-warning indicators as leaf shedding, abundant dead branches, production of epicormic shoots, abnormal crown architecture, bark necrosis, presence of pathogens, low growth rates, etc. It is still a challenge translating these indicators of change in tree vigor into a useful measure or early-warning signal which managers can safely use to forecast the probability of forest decline or tree death. Consequently, different management options, within the perspective of adaptive forest management, need to be coherently considered to favor the resilience of stands in specific sites.

In particular, during an initial phase characterized by diffuse defoliation, one of the first management actions should be oriented at increasing the soil hydrologic balance at the tree level, by considering all the vegetation components: herbs, shrubs and understory vegetation. In the presence of degraded forests, soils should preserve its capacity of water retention and the microclimatic characteristics able to favor the natural degradation of organic matter and the turnover of nutrients. In fact, in extreme cases, soil nutrient deficiency (i.e., lower levels of soil bases associated with $\mathrm{Al}$ toxicity) may cause stress and could trigger mortality and reduced growth of oak species (Demchik \& Sharpe 2000).

Thereafter, where site-specific conditions are favorable, controlled grazing could

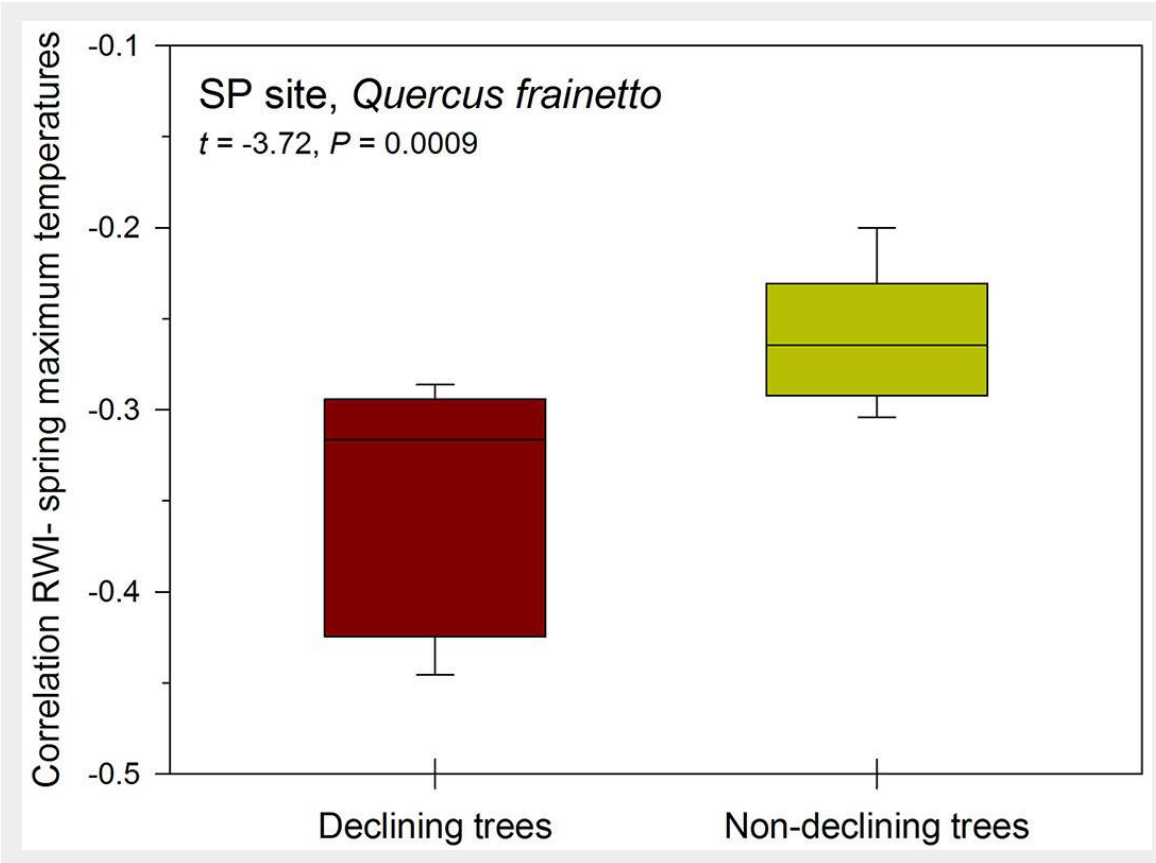

Fig. 7 - Box plots showing the correlations between individual ring-width indices (RWI) and spring mean maximum temperatures for declining and non-declining Q. frainetto trees sampled at the San Paolo (SP) site located in southern Italy (see Fig. 5). Declining trees responded more negatively to warmer conditions than non-declining trees (see statistics of the $t$-test in the upper inset). The horizontal lines within the boxes are the medians. constitute an effective management tool for keeping low evapotranspiration rates at the soil level by reducing the presence of shrubs and grasses (Sharrow \& Fletcher 1994). Moreover, in some cases, the utility of maintaining wood pasture in traditional areas could be helpful also for reducing the fuel amount, thereby decreasing the risk of fires in forest stands at drought-prone areas (Rigolot \& Etienne 1996).

Recent evidence in declining oak stands which were formerly coppices (e.g., Q. faginea, Q. ilex and Q. pyrenaica low forests in
Spain) attributed their decline to an overaging phase of trees, characterized by growth stagnation and a very low production of latewood (Corcuera et al. 2004a, 2004b, 2006). In mixed stands, Elliott \& Swank (1994) stated that mortality widely occurred in the small-size class individuals $(<10 \mathrm{~cm}$ in diameter) for all species. Moreover, Rozas \& García-González (2012) reported that trees in high competition stands showed a higher mortality risk due to the formation of earlywood vessels with small diameters.

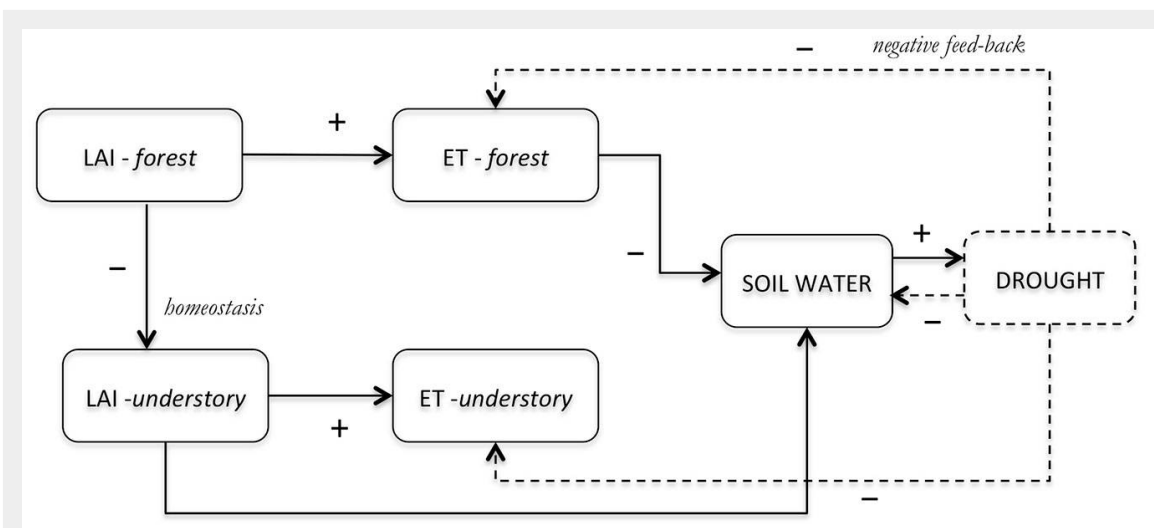

Fig. 8 - Scheme representing the homeostasis of transpiration in a forest stand, following thinning and selection cutting. The indicators draw the flow and the symbols $(+/-)$ report the quality of the relationship (positive or negative). In particular, by modulating the leaf area index of forests (LAI- forests), an increasing transpiration of trees (ET- forests) with the reduction of soil water content is expected, joined to a reduction of LAI and ET of understory vegetation. The possible negative feedbacks arising from drought stress are reported (dotted lines). 


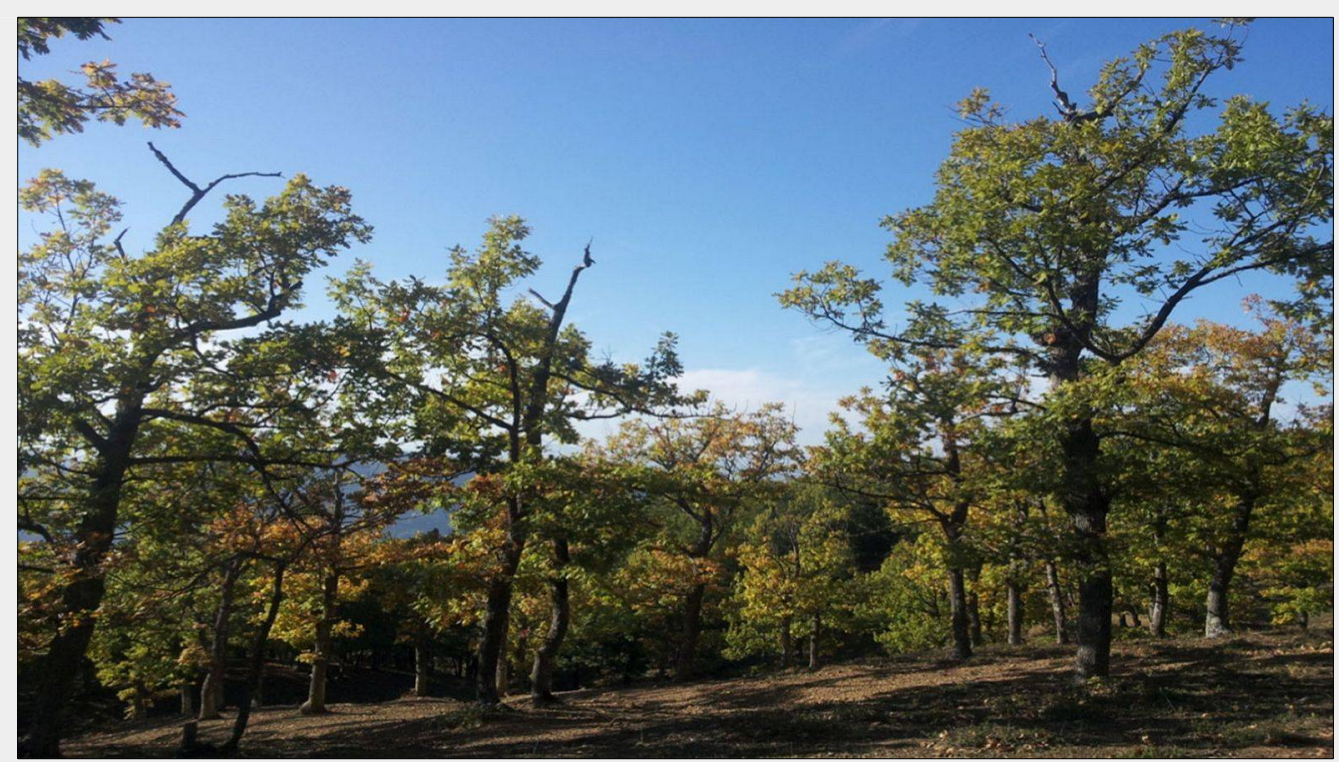

Fig. 9 - A pure Quercus frainetto stand located in Southern Italy (Oriolo, $40^{\circ} 00^{\prime}$ $\left.10^{\prime \prime} \mathrm{N}, 16^{\circ} 23^{\prime} 30^{\prime \prime} \mathrm{E}\right)$ showing symptoms of decline during the last three decades. The average age of trees is 140 years, the density is about 350 trees $^{-1}{ }^{-1}$ and more than the $40 \%$ of the standing trees show a high level of decline (crown and shoot dieback, leaf shedding, growth loss and tree mortality). Selective thinning in less degraded areas and the anticipation of the regeneration cuts in heavily degraded areas should be promoted in order to stimulate the regeneration.

In dense stands the crown and root competition for light, nutrients and water determine a reduced tree growth rate. Generally, an increasing evapotranspiration arises in the presence of a high Leaf Area Index (LAI) and an elevated density, with a negative effect on the hydrologic balance of stands. In particular, the hydraulic resistance of a stand (i.e., the ratio between the water resistance of a tree and the number of trees per stand) is expected to increase after thinning, due to the reduction of tree density. As a consequence, each single tree will increase its above and belowground biomass. Thus, deeper root systems could facilitate the water extraction from soil and raise the total individual tree water use, reducing the negative effects of drought. The increased water flux per stems will enhance the LAl, contributing to the progressively increased sapwood area of the stand. Furthermore, after thinning, the LAI will increase in the standing trees and the evapotranspiration rate, after an initial stabilization phase, will reach values similar as those observed before thinning.

According to several studies (Roberts 1983, McDowell et al. 2008), the evapotranspiration of temperate forest ecosystems is a conservative process; this homeostasis depends on the environmental control of transpiration in trees and understory layers and on the compensation processes (negative feedback) occurring at ecosystem scale (lovino et al. 2009). Moreover, homeostasis is regulated by shortand long-term physiological adjustments, both strictly linked to changes in resource availability associated with tree-to-tree competition (Fig. 8).

Management actions and silvicultural treatments, especially previous to or during dry spells, could help to regulate the equilibrium between the LAl of canopies and understory vegetation. At the stand level, sustainable harvesting aiming at reducing stand density can also result in an increased stomatal conductance that con- tributes to reducing drought-induced forest vulnerability (McDowell \& Allen 2015, Di Matteo et al. 2017). Therefore, selective thinning represents an important tool for increasing the resilience of oaks in both coppices and high-forest stands showing a high level of competition. Thinning allows to reduce the intraspecific competition, thus favoring the recovery of selected trees.

Moreover, in formerly coppiced stands, long-term management actions should redetermine the optimal coppice rotation age by shortening, if necessary, the shifts of utilization in productive stands. The gradual conversion of low forests to high forests or to multi-specific coppice stands, by favoring more drought resistant species, should also be considered where the fertility and the site-specific characteristics are suitable.

Conversely, high-forest stands need different management actions, with respect to their stand-specific composition. Monospecific high-forest stands could benefit of natural species-specific enrichment, as in mixed stands the natural regeneration of more drought resistant species is expected to contribute to the forest ecosystem equilibrium. Moreover, the establishment of different oak genotypes within stands (Valbuena \& Gil 2013) highly favors a successful adaptation to climatic changes (sensu Bravo et al. 2008). In sites seriously degraded the sexual regeneration of the stands should be promoted, preventing trees from declining and losing their ability to produce viable seeds and ensuring the continuous canopy cover. Therefore, to restore heavily degraded high-forest mixed oak stands, it could be useful to anticipate the regeneration cuts. In this way, the natural regeneration will be encouraged and will replace the declining trees, while the removal of declining and dead trees will stop the spread or incidence of pest outbreaks and pathogenic fungi, also reducing the risk of fires. Moreover, even if the regeneration of native species would not be exclusively favored, mixed oak stands with high levels of diversity should also be promoted (Hemery 2008). Several studies suggest that the maintenance of a high level of tree diversity facilitates the natural adaptation processes and increases the resilience of forest ecosystems (Lindner et al. 2010, Milad et al. 2011).

Within forests, pure stands are more susceptible to decline and more difficult to prevent by saving their natural composition. For example, most of Italian pure oak stands reported in Fig. 2 are forest types of priority habitats for the European Union (Directive 92/43/ECC) often included in protected areas with peculiar ecological importance for biodiversity conservation (see for example Fig. 9). Some of those habitats, currently subjected to non-sustainable management, are prone to decline and need flexible management strategies promoting the resilience of oak species (sensu Grant \& Edwards 2008). The loss of a single species may have profound impacts on designed protected areas, particularly when it was one of the main reasons for the designation of the reserve (Hossell et al. 2003). Often, forestry laws tend to favor a more conservative management based on close-to-nature principles in protected natural areas. Here, specific management actions should be considered for improving the resilience of declining stands. Alongside the aforementioned management actions, in particular cases it could be useful to proceed with special protection protocols with the dissemination of locally collected seeds or by planting seedlings obtained from local germplasm, in order to preserve the species-specific stand composition.

The proposed management actions should be addressed in selected areas, in order to evaluate the species-specific responses under different conditions. However, where results are not as successful as expected, management actions should be 
corrected and remodulated, following the principles of the adaptive forest management (Borghetti 2012), in order to ensure the best conditions and improve the resilience of the stands.

\section{Conclusions}

In our literature search, most of studies carried out on oak decline in Italy and Spain reported drought as the main driving factor. Although this phenomenon seems generalized and strictly related to the sitespecific conditions, drought and in general the ongoing climate warming are identified as the main threats to declining oak stands. Indeed, abandonment of the traditional use (periodic thinning) in the case of coppice forests, unfavorable site conditions (i.e., shallow soil, reduced fertility, steep slopes, etc.) combined with long-term drought stress seem to predispose oak stands to decline. Despite the almost full convergence of such studies on this topic, a lack of detailed information on the physiological mechanisms involved in oak decline still exists.

Declining oak trees are often characterized by a reduction of ring width, due to the absence or low production of latewood in ring-porous species. Decline is also associated to a decrease in lumen area of the widest vessels, those forming the earlywood in ring-porous species, and abundant lumen vessels filled with tyloses, indicating a potential decrease of hydraulic conductivity.

Recent studies found that smaller tree size and competition might worsen the effect of droughts on tree vigor. Thus, adaptive forest management strategies constitute essential tools for improving the resistance and the resilience of stands which show ongoing decline. In particular, the following practices could enhance the resilience of susceptible oak stands in drought-prone Mediterranean areas: (i) controlling the understory vegetation through targeted cuts and controlled grazing; (ii) reducing aboveground biomass through selective thinning; (iii) anticipating the regeneration cuts to stimulate seed dispersal and promote sexual regeneration; and (iv) shortening the rotation period of coppice stands. Furthermore, the identification of species, stands or trees prone to drought-induced decline could represent a valuable early-warning indicator to increase the attention and the sensibility at managing declining forests. Managing declining forests is a challenge but it has to be addressed to ensure the current level of ecosystem services that forest provides to humans and to assure their resilience in the near future.

\section{Acknowledgments}

This research arose from a communication held at the $10^{\text {th }}$ Congress of the SISEF society (2015). The work was financially supported by the project "Alarm of forest mortality in Southern Italy" (Gorgoglione
Administration, Basilicata Region, Italy). MC was supported by the PhD program from the course of Agricultural, Forest and Food Science at the University of Basilicata (Italy). Authors acknowledge three anonymous referees for their constructive comments that contributed to improve the paper. JJC acknowledges the support of the FUNDIVER project (Spanish Ministry of Economy and Competitiveness, CGL201569186-(2-1-R).

\section{References}

Adams HD, Germino MJ, Breshears DD, BarronGafford GA, Guardiola-Claramonte M, Zou CB, Huxman TE (2013). Nonstructural leaf carbohydrate dynamics of Pinus edulis during droughtinduced tree mortality reveal role for carbon metabolism in mortality mechanism. New Phytologist 197: 1142-1151. - doi: 10.1111/nph.12102

Akkemik U, Cinar Yilmaz H, Sevgl O (2006). Cambial activity of the sessile oak (Quercus petraea) in Belgrade forest, Istanbul. Turkish Journal of Agriculture and Forestry 30: 429-438.

Allen CD, Macalady AK, Chenchouni H, Bachelet $D$, McDowell $N$, Vennetier $M$, Kizberger $T$, Rigling A, Breshears DD, Hogg EH, Gonzalez P, Fensham R, Zhang Z, Castro J, Demidova N, Lim $\mathrm{JH}$, Allard G, Running SW, Semerci A, Cobb N (2010). A global overview of drought and heatinduced tree mortality reveals emerging climate change risks for forests. Forest Ecology and Management 259: 660-684. - doi: 10.1016/ j.foreco.2009.09.001

Anderegg WRL, Kane JM, Anderegg LD (2013). Consequences of widespread tree mortality triggered by drought and temperature stress. Nature Climate Change 3: 30-36. - doi: 10.1038/ nclimate1635

Avila JM, Gallardo A, Ibáñez B, Gómez-Aparicio L (2016). Quercus suber dieback alters soil respiration and nutrient availability in Mediterranean forests. Journal of Ecology 104: 1441-1452. - doi: 10.1111/1365-2745.12618

Banqué Casanovas M, Grau Ripoll A, MartínezVilalta J, Vayreda Duran J (2013). CANVIBOSC: Vulnerability of forest species to climate change. The Catalan Office for Climate Change Generalitat de Catalunya, Barcelona, Spain, pp. 77. [online] URL: http://www.creaf.cat/sites/ default/files/projects/documents/informe_canvi bosc_english.pdf

Barbero M, Loisel R, Quézel P (1992). Biogeography, ecology and history of Mediterranean Quercus ilex ecosystems. Vegetatio 99-100: 1934. - doi: 10.1007/978-94-017-2836-2_2

Barzanti GP, Capretti P, Ragazzi A (2001). Characteristics of some Phytophthora species isolated from oak forest soils in central and northern Italy. Phytopathologia Mediterranea 40: 149156. [online] URL: http://www.fupress.net/ index.php/pm/article/viewFile/1594/1529

Berdanier AB, Clark JS (2016). Multi-year drought-induced morbidity preceding tree death in Southeastern US forests. Ecological Applications 26: 17-23. - doi: 10.1890/15-0274

Besson CK, Lobo-Do-Vale R, Rodrigues ML, Almeida P, Herd H, Grant OM, David TS, Schmidt M, Otieno D, Keenan TF, Gouveia C, Mériaux C, Chaves MM, Pereira JS (2014). Cork oak physiological responses to manipulated water avail- ability in a Mediterranean woodland. Agricultural and Forest Metereology 184: 230-242. doi: 10.1016/j.agrformet.2013.10.004

Borghetti M (2012). Basic principles, mosaic of knowledges and adaptive silviculture. Forest@ 9 (4): 166-169. [in Italian with English abstract] doi: 10.3832/eforo699-009

Brasier CM (1992). Oak tree mortality in Iberia. Nature 360: 539. - doi: 10.1038/360539ao

Brasier CM (1996). Phytophthora cinnamomi and oak decline in southern Europe Environmental constraints including climate change. Annals of Forest Science 53: 347-358. - doi: 10.1051/for est:19960217

Bravo F, LeMay V, Jandl R, Von Gadow K (2008). Managing forest ecosystems: the challenge of climate change. Springer, Berlin, New York, pp. 338. - doi: 10.1007/978-3-319-28250-3

Camarero JJ, Franquesa M, Sangüesa-Barreda C (2015a). Timing of drought triggers distinct growth responses in holm oak: implications to predict warming-induced forest defoliation and growth decline. Forests 6: 1576-1597. - doi: 10.3390/f6051576

Camarero JJ, Gazol A, Sangüesa-Barreda G, Oliva J, Vicente-Serrano SM (2015b). To die or not to die: early-warning signals of dieback in response to a severe drought. Journal of Ecology 103: 44-57. - doi: 10.1111/1365-2745.12295

Camarero JJ, Sanguesa-Barreda G, Vergarechea M (2016). Prior height, growth, and wood anatomy differently predispose to drought induced dieback in two Mediterranean oak species. Annals of Forest Science 73: 341-351. - doi: 10.10 07/s13595-015-0523-4

Carnicer J, Coll M, Ninyerola M, Pons X, Sánchez G, Peñuelas J (2011). Widespread crown condition decline, food web disruption, and amplified tree mortality with increased climate change-type drought. Proceedings of the $\mathrm{Na}$ tional Academy of Sciences USA 108: 1474-1478. - doi: 10.1073/pnas.1010070108

Cater M (2015). A 20-year overview of Quercus robur L. mortality and crown conditions in Slovenia. Forests 6: 581-593. - doi: 10.339o/f6030 581

Choat B, Jansen S, Brodribb TJ, Cochard H, Delzon S, Bhaskar R, Bucci SJ, Feild TS, Gleason SM, Hacke UG, Jacobsen AL, Lens F, Maherali H, Martínez-Vilalta J, Mayr S, Mencuccini M, Mitchell PJ, Nardini A, Pittermann J, Sperry JS, Westoby M, Wright IJ, Zanne AE (2012). Global convergence in the vulnerability of forests to drought. Nature 491: 752-755. - doi: 10.1038/na ture11688

Colangelo M, Camarero JJ, Battipaglia G, Borghetti M, De Micco V, Gentilesca T, Ripullone F (2017a). A multi-proxy assessment of dieback causes in a Mediterranean oak. Tree Physiology 37 (5): 617-631. - doi: 10.1093/treephys/tpxo02

Colangelo M, Camarero JJ, Borghetti M, Gazol A, Gentilesca T, Ripullone F (2017b). Size matters a lot: drought-affected Italian oaks are smaller and show lower growth prior to tree death. Frontiers in Plant Science 8: 135 doi: 10.3389/ fpls.2017.00135

Corcuera L, Camaerero JJ, Sisò S, Gil-Pelegrin E (2006). Radial-growth and wood-anatomical changes in overaged Quercus pyrenaica coppice stands: functional responses in a new Mediterranean landscape. Trees, Structure and Func- 
tion 20: 91-98. - doi: 10.1007/s00468-005-0016-4 Corcuera L, Camarero JJ, Gil-Pelegrin E (2004a). Effects of a severe drought on Quercus ilex radial growth and xylem anatomy. Trees, Struc ture and Function 18: 83-92. - doi: 10.1007/s004 68-003-0284-9

Corcuera L, Camarero JJ, Gil-Pelegrín E (2004b). Effects of a severe drought on growth and wood anatomical properties of Quercus faginea. International Association of Wood Anatomists Journal 25: 185-204. - doi: 10.1007/s0046 8-003-0284-9

Costa A, Pereira H, Madeira M (2010). Analysis of spatial patterns of oak decline in cork oak woodlands in Mediterranean conditions. Annals of Forest Science 67: 204. - doi: 10.1051/ forest/2009097

De Nicola F, Baldantoni D, Alfani A (2014). PAHs in decaying Quercus ilex leaf litter: mutual effects on litter decomposition and $\mathrm{PAH}$ dynamics. Chemosphere 114: 35-39. - doi: 10.1016/j. chemosphere.2014.03.115

De Sampaio C, Camilo-Alves P, Esteves Da Clara MI, Cabral De Almeida Ribeiro NM (2013). Decline of Mediterranean oak trees and its association with Phytophthora cinnamomi: a review. European Journal of Forest Research 132: 411432. - doi: 10.1007/s10342-013-0688-z

Delatour C (1983). Les dépérissements de chênes en Europe [Oak decay in Europe]. Revue Forestière Francaise 35: 265-282. [in French] doi: 10.4267/2042/21659

Demchik MC, Sharpe WE (2000). The effect of soil nutrition, soil acidity and drought on northern red oak (Quercus rubra L.) growth and nutrition on Pennsylvania sites with high and low red oak mortality. Forest Ecology and Management 136: 199-207. - doi: 10.1016/S0378-1127 (99)00307-2

Di Filippo A, Alessandrini A, Biondi F, Blasi S, Portoghesi L, Piovesan G (2010). Climate change and oak growth decline: Dendroecology and stand productivity of a Turkey oak (Quercus cerris L.) old stored coppice in Central Italy. Annals of Forest Science 67: 706-710. - doi: 10.1051/forest/2010031

Di Matteo G, Nardi P, Fabbio G (2017). On the use of stable carbon isotopes to detect the physiological impact of forest management. The case of Mediterranean coppice woodland. Forest Ecology and Management 398: 158-166. - doi: 10.1016/j.foreco.2016.12.030

Elliott KJ, Swank WT (1994). Impacts of drought on tree mortality and growth in a mixed hardwood forest. Journal of Vegetation Science 5: 229-236. - doi: 10.2307/3236155

Elmquist T, Folke C, Nystrom M, Peterson G, Bengtsson J, Walker B, Norberg J (2003). Response diversity, ecosystem change and resilience. Frontiers in Ecology and Environment 1: 488-494. - doi: 10.1890/1540-9295(2003)001 [0488:RDECAR]2.0.CO;2

Fernandez-Escobar R, Gallego FJ, Benlloch $M$, Membrillo J, Infante J, Perez De Albaga A (1999). Treatment of oak decline using pressurized injection capsules of antifungal materials. European Journal of Plant Pathology 29: 29-38. - doi: 10.1046/j.1439-0329.1999.00127.x

Fisher RA, Williams M, Da Costa AL, Malhi Y, Da Costa RF, Almeida S, Meir P (2007). The response of an Eastern Amazonian rain forest to drought stress: results and modelling analyses from a throughfall exclusion experiment. Global Change and Biology 13: 2361-2378. - doi: 10.1111/j.1365-2486.2007.01417.x

Fonti P, Von Arx G, García-González I, Eilmann B, Sass-Klaassen U, Gärtner H, Eckstein D (2010). Studying global change through investigation of the plastic responses of xylem anatomy in tree rings. New Phytologist 185: 42-53. - doi: 10.1111/j.1469-8137.2009.03030.x

Gea-Izquierdo G, Fernández De Uña L, Cañellas I (2013). Growth projections reveal local vulnerability of Mediterranean oaks with rising temperatures. Forest Ecology and Management 305: 282-293. - doi: 10.1016/j.foreco.2013.05.058 Gentilesca T, Camele I, Colangelo M, Lauteri M, Lapolla A, Ripullone F (2015). Oak forest decline in southern Italy: the study case of Gorgoglione forest. In: Proceedings of the " 2 nd International Congress of Silviculture". Florence (Italy) 26-29 Nov 2014. Accademia Italiana di Scienze Forestali, Florence, vol. II: 123-129. [online] URL: https://aisfdotit.files.wordpress.com/2016/03/v ol_2_2cis_rev.pdf

Gleason SM, Westoby M, Jansen S, Choat B, Hacke UG, Pratt RB, Bhaskar R, Brodribb TJ, Bucci SJ, Cao KF, Cochard H, Delzon S, Domec JC, Fan ZX, Feild TS, Jacobsen AL, Johnson DM, Lens F, Maherali H, Martínez-Vilalta J, Mayr S, Mcculloh KA, Mencuccini M, Mitchell PJ, Morris H, Nardini A, Pittermann J, Plavcová L, Schreiber SG, Sperry JS, Wright IJ, Zanne AE (2016). Weak tradeoff between xylem safety and xylem-specific hydraulic efficiency across the world's woody plant species. New Phytologist 209 (1): 123-136. - doi: 10.1111/nph.13646

González Alonso C (2008). Analysis of the oak decline in Spain: la seca. Swedish University of Agricultural Sciences. Bachelor Thesys, Uppsala, Sweden, pp. 74. [online] URL: http:// stud.epsilon.slu.se/55/1/Oak_Decline_Clara_Go nzález Alonso.pdf

Grant MJ, Edwards ME (2008). Conserving idealized landscapes: past history, public perception and future management in the New Forest (UK). Vegetation History and Archaeobotany 17: 551-562. - doi: 10.1007/s00334-007-0100-3

Greenwood S, Ruiz-Benito P, Martínez-Vilalta J, Lloret $F$, Kitzberger $T$, Allen $C D$, Fensham R, Laughlin DC, Kattge J, Bönisch G, Kraft NJB, Jump AS (2017). Tree mortality across biomes is promoted by drought intensity, lower wood density and higher specific leaf area. Ecology Letters 20: 539-553. - doi: 10.1111/ele.12748

Gutiérrez E, Campelo F, Camarero JJ, Ribas M, Muntán E, Nabais C, Freitas H (2011). Climate controls act at different scales on the seasonal pattern of Quercus ilex L. stem radial increments in NE Spain. Trees, Structure and Function 25: 637-646. - doi: 10.1007/s00468-011-05 40-3

Haavik LJ, Billings SA, Guldin JM, Stephen FM (2015). Emergent insects, pathogens and drought shape changing patterns in oak decline in North America and Europe. Forest Ecology and Management 354: 190-205. - doi: 10.101 6/j.foreco.2015.06.019

Hannah L, Midgley GF, Millar D (2002). Climate change-integrated conservation strategies. Global Ecology and Biogeography 11: 485-495. doi: 10.1046/j.1466-822X.2002.00306.x
Hartmann H, Adams HD, Anderegg WRL, Jansen $S$, Zeppel M (2015). Research frontiers in drought-induced tree mortality: crossing scales and disciplines. New Phytologist 205: 965-969. doi: 10.1111/nph.13246

Hemery GE (2008). Forest management and silvicultural responses to projected climate change impacts on European broadleaved trees and forests. The International Forestry Review 10: 591-607. - doi: 10.1505/ifor.10.4.591

Hoffmann WA, Marchin RM, Abit P, Lau OL (2011). Hydraulic failure and tree dieback are associated with high wood density in a temperate forest under extreme drought. Global Change Biology 17: 2731-2742. - doi: 10.1111/j.136 5-2486.2011.02401.x

Hossell JE, Ellis NE, Harley MJ, Hepburn IR (2003). Climate change and nature conservation: Implications for policy and practice in Britain and Ireland. Journal of Nature Conservation 11: 67-73. - doi: 10.1078/1617-1381-00034 lovino F, Borghetti M, Veltri A (2009). Forests and water cycle. Forest@6: 256-273. [in Italian with English abstract] - doi: 10.3832/eforo583006

IPCC (2014). Climate change 2014: impacts, adaptation, and vulnerability. Part A: global and sectoral aspects. Contribution of Working Group II to the Fifth Assessment Report of the Intergovernmental Panel on Climate Change. Cambridge University Press, Cambridge, UK, pp. 1435 .

Lebourgeois F, Cousseau G, Ducos Y (2004). Climate-tree-growth relationships of Quercus petraea Mill stand in the Forest of Berce ("Futaie des Clos", Sarthe, France). Annals of Forest Science 61: 361-372. - doi: 10.1051/forest:2004029 Levanic T, Matjaz C, McDowell NG (2011). Associations between growth, wood anatomy, carbon isotope discrimination and mortality in a Quercus robur forest. Tree Physiology 31: 298308. - doi: 10.1093/treephys/tpq111

Linaldeddu BT, Franceschini A, Luque J, Philips AJL (2007). First report of canker disease caused by Botryosphaeria parva on cork oak trees in Italy. Plant Disease Journal 91: 324 . doi: 10.1094/PDIS-91-3-0324A

Linaldeddu T, Sirca C, Spano D, Franceschini A (2009). Physiological responses of cork oak and holm oak to infection by fungal pathogens involved in oak decline. Forest Pathology 39: 232-238. - doi: 10.1111/j.1439-0329.2008.00579.x Linaldeddu T, Sirca C, Spano D, Franceschini A (2010). Variation of endophytic cork oak-associated fungal communities in relation to plant health and water stress. Forest Pathology 41: 113 .

Linaldeddu BT, Scanu B, Maddau L, Franceschini A (2014). Diplodia corticola and Phytophthora cinnamomi: the main pathogens involved in holm oak decline on Caprera Island (Italy). Forest Pathology 44: 191-200. - doi: 10.1111/efp.120 81

Linares JC, Camarero JJ, Carreira JA (2009). Interacting effects of climate and forest-cover on mortality and growth of the southernmost European fir forests. Global Ecology and Biogeography 18: 485-497. - doi: 10.1111/j.1466-823 8.2009.00465.x

Linares JC, Camarero JJ (2012). Growth patterns and sensitivity to climate predict silver fir de- 
cline in the Spanish Pyrenees. European Journal of Forest Research 131: 1001-1012. - doi: 10.1007/ s10342-011-0572-7

Lindner M, Maroschek M, Netherer S, Kremer A, Barbati A, Garcia-Gonzalo J, Seidl R, Delzon S, Corona P, Kolströma M, Lexer MJ, Marchetti M (2010). Climate change impacts, adaptive capacity, and vulnerability of European forest ecosystems. Forest Ecology and Management 259: 698-709. - doi: 10.1016/j.foreco.2009.09. 023

Lloret F, Siscart D, Dalmases C (2004). Canopy recovery after drought dieback in holm-oak Mediterranean forests of Catalonia (NE Spain). Global Change Biology 10: 2092-2099. - doi: 10.1111/j.1365-2486.2004.00870.x

Manion PD (1991). Tree disease concepts $\left(2^{\text {nd }}\right.$ edn). Prentice-Hall, Upper Saddle River, NJ, USA, pp. 416.

Marçais B, Bréda N (2006). Role of an opportunistic pathogen in the decline of stressed oak trees. Journal of Ecology 94: 1214-1223. - doi: 10.1111/j.1365-2745.2006.01173.x

Martínez-Vilalta J, Lloret F, Breshears D (2011). Drought-induced forest decline: causes, scope and implications. Biology Letters: 689-691. doi: 10.1098/rsbl.2011.1059

McDowell NG, Allen CD (2015). Darcy's law predicts widespread forest mortality under climate warming. Nature Climate Change 5: 669-672. doi: $10.1038 /$ nclimate2641

McDowell NG, Pockman WT, Allen CD, Breshears DD, Cobb N, Kolb T, Plaut J, Sperry J, West A, Williams DG, Yepez EA (2008). Mechanisms of plant survival and mortality during drought: why do some plants survive while others succumb to drought? New Phytologist 178: 719739. - doi: 10.1111/j.1469-8137.2008.02436.x

Mencuccini M, Minunno F, Salmon Y, MartinezVilalta J, Hölttä T (2015). Coordination of physiological traits involved in drought-induced mortality of woody plants. New Phytologist 208: 396-409. - doi: 10.1111/nph.13461

Milad M, Schaich H, Bürgi M, Konold W (2011). Climate change and nature conservation in Central European forests: a review of consequences, concepts and challenges. Forest Ecology and Management 261: 829-843. - doi: 10.1016/j.foreco.2010.10.038

Montserrat-Martí G, Camarero JJ, Palacio S, Pérez-Rontomé C, Milla R, Albuixech J, Maestro M (2009). Summer-drought constrains the phenology and growth of two co-existing Mediterranean oaks with contrasting leaf habit: impli- cations for their persistence and reproduction. Trees, Structure and Function 23: 787-799. - doi: 10.1007/s00468-009-0320-5

Morillas L, Gallardo A, Portillo-Estrada M, Covelo F (2011). Nutritional status of Quercus suber population under contrasting tree dieback. Forestry 85: 369-377. - doi: 10.1093/forestry/cps035 Nakajima H, Ishida M (2014). Decline of Quercus crispula in abandoned coppice forests caused by secondary succession and Japanese oak wilt disease: stand dynamics over twenty years. Forest Ecology and Management 334: 18-27. doi: 10.1016/j.foreco.2014.08.021

Nixon KC (2006). Global and Neotropical distribution and diversity of oak (genus Quercus) and oak forests. In: "Ecology and Conservation of Neotropical Montane Oak Forests" (Kappelle $M$ ed). Ecological Studies, vol. 185, Springer-Verlag, Berlin, Heidelberg, Germany, pp. 313. - doi: 10.1007/3-540-28909-7_1

O’Brien MJ, Engelbrecht BMJ, Joswig J, Pereyra G, Schuldt B, Jansen S, Kattge J, Landhäusser SM, Levick SR, Preisler $Y$, Väänänen $P$, Macinnis-Ng C (2017). A synthesis of tree functional traits related to drought-induced mortality in forests across climatic zones. Journal of Applied Ecology: 18. - doi: 10.1111/1365-2664.12874

Perez-Sierra A, Lopez-Garcia C, Leon M, GarciaJimenez J, Abad-Campos P, Jung T (2013). Previously unrecorded low-temperature Phytophthora species associated with Quercus decline in a Mediterranean forest in eastern Spain. Forest Pathology 43: 331-339. - doi: 10.1111/efp.120 37

Rigolot E, Etienne M (1996). Litter thickness on tree covered fuel-breaks maintained by grazing. In: "Western European Silvopastoral System" (Etienne $M$ ed). Institut National de la Recherche Agronomique, Paris, France, pp. 111122.

Roberts J (1983). Forest transpiration: a conservative hydrological process? Journal of Hydrology 66: 133-141. - doi: 10.1016/0022-1694(83)901 81-6

Rozas V, García-González I (2012). Too wet for oaks? Inter-tree competition and recent persistent wetness predispose oaks to rainfall-induced dieback in Atlantic rainy forest. Global and Planetary Change 94- 95: 62-71. - doi: 10.101 6/j.gloplacha.2012.07.004

Rozas V, Sampedro L (2013). Soil chemical properties and dieback of Quercus robur in Atlantic wet forests after a weather extreme. Plant and Soil 373: 673-685. - doi: 10.1007/s11104-013-1835-
5

Sala G, Giardina G, La Mantia T (2011). I fattori di rischio per la biodiversità forestale in Sicilia: il caso studio del cerro di Gussone [Risk factors for forest biodiversity in Sicily: the study case of Quercus gussonei (Borzi) Brullo]. L'Italia Forestale e Montana 66: 71-80. [in Italian] - doi: 10.4129/ifm.2011.1.06

Scanu B, Linaldeddu BT, Franceschini A, Anselmi $\mathrm{N}$, Vannini A, Vettraino AM (2013). Occurrence of Phytophthora cinnamomi in cork oak forests in Italy. Forest Pathology 43: 340-343. - doi: 10.1111/efp.12039

Sharrow SHS, Fletcher RA (1994). Trees and pastures: 40 years of agro-silvopastoral experience in Western Oregon. In: Proceedings of the Symposium "Agroforestry and Sustainable Systems". Fort Collins (CO, USA) 7-10 Aug 1994. NAC, Lincoln, NE, USA, pp. 47-53.

Siwecki R, Liese W (1991). Oak decline in Europe. In: Proceedings of an International Symposium held in Kornik (Poland) 15-18 May 1990. Poland Institute of Dendrology, Polish Academy of Sciences, PWRiL, Poznań, Poland, pp 360.

Tainter FH, Williams TM, Cody JB (1983). Drought as a cause of oak decline and death on the South Carolina coast. Plant Disease 67: 195-197. - doi: 10.1094/PD-67-195

Tessier L, Nola P, Serre-Bachet F (1994). Deciduous Quercus in the Mediterranean region: treering/climate relationships. New Phytologist 126: 355-367. - doi: 10.1111/j.1469-8137.1994.tbo395 5.x

Tulik M (2014). The anatomical traits of trunk wood and their relevance to oak (Quercus robur L.) vitality. European Journal of Forest Research 133: 845-855. - doi: 10.1007/s10342014-0801-y

Valbuena M, Gil L (2013). Genetic resilience in a historically profited root sprouting oak (Quercus pyrenaica Willd.) at its southern boundary. Tree Genetics and Genomes 9: 1129-1142. - doi: 10.1007/s11295-013-0614-z

Vettraino M, Barzanti GP, Bianco MC, Ragazzi A, Capretti P, Paoletti E, Luisi N, Anselmi N, Vannini A (2002). Occurrence of Phytophthora species in oak stands in Italy and their association with declining oak trees. Forest Pathology 32: 19-28. - doi: 10.1046/j.1439-0329.2002.00264.x Wyckoff PH, Bowers R (2010). Response of the prairie-forest border to climate change: impacts of increasing drought may be mitigated by increasing $\mathrm{CO}_{2}$. Journal of Ecology 98: 197208. - doi: 10.1111/j.1365-2745.2009.01602.x 